\title{
Journalists' collective representation and editorial content in newspapers
}

Purpose: This article examines the intriguing juxtaposition of a bona fide independent union for journalists in Britain which is vocal about editorial standards and interference yet has seldom taken collective action to respond to such instances.

Design/methodology/approach: A grounded approach to this phenomenon used is used by way of examining the intersection of the nature and influence of journalistic professionalism, the journalists' material and economic interests and the particular approach of the union to both these matters. The data is based on qualitative fieldworks supplemented by secondary sources.

Findings: The journalists and their union have yet to identify and articulate, and the conditions which give rise to these, a strategy for defending their professional interests which is compatible with and supportive of strategies for defending their material interests. Practical implications: There is a need to develop a strategy by which journalists can collective exert more influence over editorial content.

Social implications: The quality of content of newspapers could be enhanced by the greater influence of journalists as a collective body.

Keywords: journalists, collective action, editorial content, Britain

Type of paper: research paper 


\section{Journalists' collective representation and editorial content in British newspapers}

\section{Introduction}

The dominant explanations of the processes and dynamics by which the editorial content of newspapers in Britain is created and determined focus upon, inter alia; the role of prevailing ideologies in capitalist society, the function of newspapers in a capitalist society as reproducers of social norms and forms of social control, the power of proprietors and editors, the influence of interest groups such as political parties, governments and businesses in setting news agendas, newspapers as units of capital in a regime of capital accumulation and the function of journalists as professionals-cum-journalism as a profession (Beharrell and Philo 1977, Davies 2008, Franklin and Murphy 1991, 1998, Sparks 1999, and Tunstall 1971). To the extent that journalists may be viewed as a collective agency in the form of a profession which may then exert influence upon editorial content, one of two positions tends to pervade analysis and comment. The first is that issues of discourse-asprofession are held to be relatively unproblematic, especially in the critical realm of the interaction of those main sub-groups that quintessentially constitute the profession, namely, journalists and editors. Journalists are seen here to form alliances with editors to uphold standards in the face of proprietorial and managerial pressure to cut costs and chasing rising sales by going 'down market'. Here, editors are seen to try to mitigate and ameliorate those pressures in order to protect the product and the journalists. The second is that journalists in Britain, at any rate, are held not to constitute an actual profession where a profession is defined, not as a desirable occupation, but as a specific community which has specialist knowledge, controls entry to itself, and regulates its members' behaviours through establishing standards and ethics. Even where the focus is specifically upon journalists' ethics (see, for example, Keeble 2001, Frost 2007, Sanders 2003), it is hard to find studies that examine the influence of journalists on editorial content where journalists are 
constituted as a collective body that represents a conscious, coherent and specific interest group at the point of origination (save Harcup 2002a, 2004, and to a varying but small extent: Bromley 1997, Franklin and Murphy 1997, and Tunstall 1971). For example, Chris Frost (2007:276) as a former NUJ President but also then chair of the NUJ's Ethics Council, made only one very brief consideration of the bearing of journalists' collective influence upon issues of standards and content through noting the fall of the necessity of holding an NUJ card - a situation akin to a closed shop. This was in spite of according the NUJ a central role in the upholding and enforcement of ethics through its Code of Conduct - albeit it through individual means of exhortation. In such a situation, Harcup (2002a:112) concluded: '[A]ny critique of the ethics of journalism that fails to address the role of journalists as workers can only be partial'. Moreover, there have been just a few radical practitioner voices like Paul Foot (1991:7-8) in Britain that have called for journalists to be able to collectively exert some element of control over editorial content - not just to remedy the worst excesses of contemporary newspapers but also to constitute a mainstream and regular legitimate influence.

In a broadly similar vein to Harcup (2002a, 2004, 2007), this article seeks to explore the presence and absence of the collective influence of journalists as workers on the editorial content of provincial and national newspapers in Britain. The approach deployed here is not to counter-pose the overly-narrow approach of the 'process and politics of production' of a conventional labour process theory perspective to that of the dominant perspective from media studies of explaining journalism in the light of prevailing values in society and the institutional function of newspapers for this would constitute an unproductive binary of the, so to speak, 'internal' versus 'external'. Neither, is it to take a position of merely stating that both perspectives have a place in explaining editorial content outcomes without assessing their relative strengths and the determinants of these. Rather, the approach is an attempt to 
view the process of origination of editorial content as a potential site of struggle between journalists and employers and their management, where the relationship between the 'process of production' perspective and dominant societal norms can be integrated, articulated and contextualised. In short, it is to seek to understand the editorial outcome of the relationship between not just potentially competing values and discourses but also interests and powers and do so within the origination-cum-production process.

But, in contrast to Harcup's (2002a) study, this article is not primarily concerned with the ethics of journalists and journalism in Britain as per the National Union of Journalists (NUJ)'s Code of Conduct (see Appendix). The Code of Conduct concerns itself primarily with the manner in which journalism is carried out and, because it is conceived in terms of tackling the 'rough edges' and not the polity of journalism, it does not concern itself with content per se and is unconcerned with the aspirant function of journalism as the 'sword of justice' or as the discussant and analyser (rather than just reporter or as reportage) of weighty matters. Rather this article, however, is concerned with the wider issue of what can be termed 'weighty' and 'worthwhile' journalism and journalists' collective search for, and defence of, such journalism through collective interest representation and mobilisation via their union, the NUJ.' Consequently, this study examines a terrain of collective struggle which is primarily located at the workplace, in the origination process and amongst a collective of workers, rather than at the primarily individual level (i.e. an individual NUJ member abiding by or contravening the Code of Conduct) or in the forum of NUJ policy and outside the workplace (i.e. the NUJ Ethics Council, or the NUJ Annual Delegate Conference). The highpoint of this collective, workplace-based struggle is viewed as being collective industrial action, whether a strike or industrial action short of a strike for two reasons. On the one hand, such action has the potential ability to create the greatest leverage over the employer by disrupting or halting production while, on the other hand, it indicates that the journalists have - even if 
only temporarily - crossed the proverbial Rubicon by hurting the newspaper they work for in the short-term for its defence in the long-term.

Given that the NUJ represents the vast majority of journalists within collective trade union organisations for journalists in Britain ${ }^{\mathrm{ii}}$ and that the NUJ represents around $50 \%-60 \%$ of newspapers journalists, it is an appropriate body to use as a prism by which to examine the issues at hand. But more than this, the NUJii comprises not merely a union organisation as defined by its role in defending and advancing its members' (as workers) economic basedinterests but it also undertakes a further role as a professional body for journalists concerned with the pursuit of an ideal type of journalism. This ideal type, indeed, the 'ideal' of journalism, involves the profession or agency of journalism being not only the discoverer of truth and the upholder of truth but also the scrutineer of the rich and powerful and of vested interests where the notion of the 'fourth estate' is to act as a counterweight to other agencies in the body politic and to exercise the 'sword of justice' for groups too weak and ineffectual to do so themselves. If the pervasiveness of this ideal among journalists is any way widespread, then one would expect, all other things being equal, it to rear its head within the behaviour and practice of newspaper journalists.

Other than the salience of raising the issue of journalists' collective influence on editorial content in the abstract or in an historical context, why might it arise in the period of the late 1990s/early 2000s? There are three reasons. First, it is a widely held belief that as the concentration of ownership in newspapers grows amongst a small number of large units of, often transnational, capital, so too does the centralisation of control of these newspapers, the standardisation of output and the bowdlerisation of product with deleterious consequences for diversity of coverage, perspectives and positions. Second, the increasing power of the shareholder value agenda and the use of private equity funded takeovers in an 
era of full-blown neo-liberalism have meant that journalists in the contemporary period have become processors rather than finders or gatherers of information as they now have neither the time nor resources to do so because of cuts in staffing. Then are then susceptible to simply refashioning the press releases and news feeds of those organisations which employ journalists to write their press releases and provide new feeds in an immediately digestible way (see Davies (2008) on 'churn-alism' and 'churn-alists'). Here the NUJ's Journalism Matters political campaign of 2006 onwards, highlighting that profits reduce quality by cutting jobs, is apposite. Linked to this process is another, whereby the power of proprietors, editors and group editorial directors to determine editorial content has also increased as a result of the diminution of the collective power of journalists resultant upon the derecognition and marginalisation of the NUJ. Third, and since 2000, the NUJ has begun to makes significant steps towards recapturing earlier lost ground by regaining union recognition agreements with employers in the provincial and national newspaper sectors (Gall 2002, 2004). Moreover, it has subsequently engaged in some industrial action in pursuit of improving wages and conditions (Gall 2005a, 2005b). This then opens up the possibility of union renewal and, with it, the opportunity for contesting the current discourses that determine editorial content. Indeed, Harcup (2002a:111) made a similar proposition:

If there were few instances of journalists taking collective stands on issues when their jobs were secure and their union relatively strong, there have been even fewer since the postWapping employers' offensive led to unconstrained management prerogative ... [But] the prospect of journalists raising ethical concerns through their collective organisation, the NUJ, appears more likely in a climate where the union has a voice that is recognised than in an aggressively anti-union atmosphere

The data for the article is derived from material gathered over the last twenty years researching the industrial relations of provincial and national newspapers through primary sources (interviews with lay and full-time NUJ officers) and secondary sources (the 
journalists' then weekly trade magazine, Press Gazette, and the NUJ's membership magazine, Journalist, and its press releases). More specifically, over 100 interviews were conducted between 1989-2003 and were concerned with exploring the effect of an employers' derecognition offensive on the ability of the NUJ to contest and shape the terms of the employment relationship, and more latterly, to regain union recognition and then engage in effective collective bargaining. This necessarily included, albeit as a minor part, the issues of journalists' influence over the editorial content of the newspapers they worked on. The article proceeds by noting the paucity of journalists' collective action over editorial matters before moving to explore a number of instances of these in order to begin to lay out an explanation for their infrequency. This revolves particularly around the influence of professionalism and the particular approach taken by the NUJ to these matters.

\section{Combined absence of action and study}

The principled, if infrequent, actions of individual journalists refusing to reveal their sources or their notebooks to the police and courts in order to maintain the integrity of the journalistic process have been extensively documented in the public domain (see Gopsill and Neale 2007, Keeble 2001:29-31). The same cannot be said of the prima facie but equally sparse incidence of collective actions by journalists to do similarly. The paucity of any study of the collective influence of journalists over editorial content appears to be (positively) related not merely to the actual paucity of such actions but also an implicit prejudice against consideration because of the collective nature of this action. Nonetheless, the absolute sparseness of collective workplace-based action by newspaper journalists over editorial content, whether of a defensive and reactive nature (against editorial lines) or of an offensive and proactive nature (for editorial lines) can be noted. Harcup (2002a:108-109) drawing on Hollingswood (1986) provides a catalogue of the few examples of collective 
concern up to the mid-1980s, concluding that: 'while [journalists] may or may not have critical views as individuals, at an everyday level journalists tend not to see editorial or ethical considerations as issues for collective or labour union intervention' (Harcup 2002a:109) and that up to 2002: 'cases of journalists combining to question their own employers' editorial, rather than industrial, practices have been few and far between' (Harcup 2002b:13). To these can be added just a few more (see below). Continuing in the same vein, Harcup (2007:122) argued that: 'NUJ chapels do not usually concern themselves with editorial content or ethics, being more bothered about 'bread and butter' issues' (see also Harcup 2007:132), while Hollingsworth (1986:25) himself made a similar point: 'British journalists have rarely, if ever, taken any kind of industrial action to protest'.

But before looking at the sparse evidence of collective industrial action mobilisations by journalists, it is still worth recognising that the collective consciousness and collective actions of journalists with regard to editorial issues cannot be solely judged by the presence or absence of collective industrial action over editorial issues. Although a case has been made earlier for industrial representing the apex of the power of leverage, other forms of collective non-industrial action - like chapel meetings which pass motions of no-confidence in editors and proprietors or attempting to cause political embarrassment to editors and proprietors by 'going public' on issues - can play a role in the pursuit of journalists' interest representation, either as a direct complement or where industrial action is unobtainable as a result of members' lack of collective confidence. This is all the more so as such instances are potential (rather than probable) wellsprings for collective industrial action given that they indicate an active collective oppositional consciousness. So while collective industrial action, for reasons outlined below, is more identifiable and newsworthy, there have been many occasions when collective discussions in chapels and branches (workplace and extraworkplace units of NUJ organisation) have taken place over editorial issues and content, 
albeit these have been less frequent than discussion of overt issues of pay and conditions. For example, Harcup (2002a, 2002b) reported on some instances in the provincial press (in Birmingham, Liverpool and Newcastle) of concern over editorial content and styles of journalism and the subject has been aired frequently in the Journalist (see also Harcup 2007:chapter 9). The difficulty in identifying such actions is derived from the lack of tangible, positive outcomes from such discussions as well as the absence of study of the production and labour processes under which journalists work.

\section{Journalists confront editors and employers over editorial content}

In the last decade or so, only a few more instances can be added to the list drawn up by Hollingsworth (1986) and Gopsill and Neale (2007) of collective workplace-based action being taken by journalists on editorial issues. The former recounted just one (with more examples of journalists refusing to act collectively when petitioned or siding with management) and the latter just four examples in newspapers in Britain while Harcup (2007) added just two more instances. Indeed, Gopsill and Nealed (2007) reported that often a chapel would take the form of action of calling upon the Press Complaints Commission to act rather than act itself. This sits oddly with former Daily Mirror editor and newspaper commentator Greenslade's $(2003: 247,283)$ interpretation of the national press in the 1970s and 1980s:

Owners and editors, rightly fearing that journalists would use their union strength not only for bargaining over wage and conditions but also as leverage to control the editorial content of their papers, were determined not to allow the NUJ to win closed-shop rights. ... [E]specially the younger [more radical] element [of the NUJ] ... realised it could be a political lever to curb the owners' power over editorial content.

The problem with this interpretation is that subsequently Greenslade (2003:284) effectively rendered it invalid by stating: 
It had been conveniently overlooked that closed shops, in all but name, had existed for years [at the Mirror, Express and Sun national newspaper groups] ... Apart from using their leverage to ensure only union members wrote copy and took pictures, there were no cases in Fleet Street of NUJ closed shops being used to prevent editors publishing what they liked.

Additionally, the few extant instances also sit rather oddly with the pleas by some eminent journalists and NUJ to make editorial issues and enforcement of the NUJ Code of Conduct a collective matter backed by industrial action (see Gopsill and Neale 2007:245).

So in addition to bringing the further examples to a wider attention, it is also worth detailing these examples in order to have an appreciation of the circumstances in which they arose given their sparseness. Indeed, this might serve to go some way to explaining their sparseness.

The first concerns the Mirror in the early 1990s, and specifically, the partial occupation by journalists of the space in which editorial content was determined during the hiatus after the death of Robert Maxwell and the resultant relatively arms length control of the newspaper by legal administrators in 1991. For a period of about a year, journalists heavily influenced the content and direction of the newspaper in a way they had not before (see Gall 1997). Upon the appointment of former News International and Murdoch manager, David Montgomery, in 1992, the journalists rebelled in the form of a mandatory work-time meeting, fearing for their editorial independence, the paper's pro-Labour line, their jobs and for the continuation of union recognition. Had their meeting not ended when it did, after securing pledges on these issues, the paper would have not been produced that night. Also in 1991, the NUJ chapel South Wales Argus in Newport refused to handle the copy on a story about an industrial tribunal involving the company after the editor changed it to make the company look better (Gall and Murphy 1996:241). 
Nearly a decade later, NUJ chapels and regional councils expressed publicly criticisms and concerns over a number of instances of newspapers' coverage. These concerned coverage of racial issues in the north of England (Journalist January 1999) and homophobic coverage of the scrapping of the anti-homosexual Clause 28 in Scotland (Journalist April 2000). In 2001, the NUJ chapel at the Express Group (Daily Express, Sunday Express) passed a motion condemning the 'confrontational racist hatred' in the papers' coverage of asylum seekers (Journalist September 2001). At the Telegraph Group in late 2003-early 2004, the NUJ chapel expressed grave concerns over the possibility of pornographer Richard Desmond taking over the papers after the downfall of Conrad Black and the collapse of his control over Hollinger, the holding company. The concerns focussed on maintaining the editorial quality expected of a broadsheet newspaper and his style of management. When a bid from German publisher, Axel Springer, appeared likely to be successful, the chapel protested at the possibility of being required to sign up to its five 'essential principles' which included support for further European unification, the state of Israel and the free social market economy. Finally, Daily Star NUJ member journalists in 2006 threatened to unspecified action against anti-Muslim spoof which was then withdrawn.

The following examples of acute and collective concern over the behaviour of editors and proprietors as a result of third party intervention are rare. At a small north-east of Scotland weekly newspaper, journalists protested against the future vetting of copy which was of a commercially sensitive by the company after it lost business from an advertiser following a critical story (Press Gazette 16 September 2000). A year later, the NUJ chapel supported one its members protesting against political interference and company complicity in this at the Wishaw Press (Herald 22 November 2001, see also Journalist January/February 2002). The Wishaw Press reporter incurred the wrath of the First Minister in Scotland over coverage of 
his expenses. This led to the First Minister being given the right, by the editor, to vet copy on the issue and any other copy concerning him - an agreement which the reporter refused to accept. The NUJ protest led to this concession being withdrawn by virtue of the denial that it had ever been granted.

The underlying context of the majority of these instances is significant. The Mirror chapel had become reinvigorated after successfully facing down Maxwell a year earlier over redundancies by using a mandatory work-time meeting to prevent publication of the paper. At the Express Group, full union recognition had just been regained and some significant improvements in terms and conditions of employment had been achieved through a threatened strike. The events in Scotland took place in an environment where derecognition had largely been absent and where union membership was higher than in England. Finally, at the Telegraph Group, the chapel had regained recognition recently and had balloted for strike action on pay at the time. The first two examples (Mirror, South Wales Argus) took place as the derecognition offensive began and when the NUJ was not yet marginalised. The next examples took place in the period in which the NUJ had begun to win back recognition, beginning to undo its marginalisation. The thrust of this is not to suggest a direct or causal link but rather to infer that union collective reawakening and mobilisation are generally conducive to the expression of other collective concerns vis-a-vis condemnation of management. Moreover, some of these instances have been located in periods of crisis and significant transition at the newspapers, suggesting that an air of abnormality in the structures and processes of managerial control may again be conducive to such expressions.

The overall rarity of such instances of collective protestant action relates not just to the journalists' actions themselves but also the stimuli to their actions. Such overt and naked behaviour of editors and proprietors appears to be rare, raising the question of whether 
'interference' takes place in a more subtle and covert way and whether, if this is the case, journalists are capable of identifying, as well as acting against, it. ${ }^{\text {iv }}$ The rise of 'advertorial' in the provincial newspapers, where there is not a clear and transparent divide between editorial copy and advertising copy (see Gall 1993), and of 'freebie' journalism where journalists are often individually and collectively complicit in corruption and unethical behaviour in regard of travel, business and consumer journalism (Browne 2002) suggests that journalist do not necessarily always identify it as a malaise and act against it. Browne (2002:21) ventured: 'Journalists are the nation's anti-corruption squad, but there is no one to investigate our own corruption. All the public can rely upon is our integrity and sense of fair play. They are being let down'.

In addition to this, there other means of expressing discontent. Thus, a far more common occurrence is the individual exit strategy (see also Gall and Murphy 1996:243). As with discontent over working conditions, as with discontent over editorial direction and content, journalists have exercised their ability to leave a particular newspaper and gain employment at another newspaper or in another form of media, or else go freelance, to respond to discontent over editorial direction and content. While subject to the buoyancy of the labour market, the normal path involves individual grumbling becoming semi-collective grumbling within and without the workplace (e.g. the pub) prior to the threshold of 'enough is enough' being crossed and stimulating job applications. For example, but somewhat unusually, as many as thirty journalists from the Scotsman in Edinburgh in 2000 took the opportunity to move to the short-lived business am when it was established in Edinburgh.

\section{Professionalism: bulwark against, and spur to, collective action}


Whilst the creation of the NUJ as a breakaway from the Institute of Journalists (IOJ) and then its subsequent organisational hegemony amongst journalists emphasised the importance of trade unionism over professionalism, professionalism has nonetheless remained a potent force amongst the NUJ and its members. Most obviously, professionalism can tend toward a belief in the unity of interests between a) journalists and newspapers as journalism, and b) journalists and newspapers, where it exists as phenomenon which stresses common purpose in pursuit of enhanced status for a learned activity and for 'worthy' journalism (Gall and Murphy 1996).

However, the cost-cutting and profit-seeking behaviour of newspaper employers has led many journalists to couch their professionalism in terms of being a defender of 'worthy' journalism and laudable news values, thereby, leading to the atrophy of the perception of unity of interests between journalists and newspapers-cum-companies and journalists and companies. This can then be seen as a necessary but not sufficient condition to the creation of collective action over editorial matters. However, the unity of interests between journalists and newspapers can still act as a de facto support to the companies where journalists do not wish to take any action (e.g. industrial action) which might 'hurt' the newspaper or take action to support the newspaper (such as cover for short-staffing by working longer hours). So while it would be wrong to suggest that the factor of professionalism alone can account for the paucity of journalists' collective action over editorial content, it does play an important role in helping to explain why collective concern may have varying outcomes. Alongside it must stand a consideration of journalists' collective strength and wider collective consciousness. The crux to understanding the particular role professionalism plays is to understand the indeterminant and contingent nature of the situations in which such collective concerns over editorial content exist. Therefore, the next 
section examines the most common expression of journalists' collective expression of concern over editorial issues.

\section{Editorial quality concerns as adjunct to bargaining}

NUJ members have most commonly expressed collective concern over issues of editorial quality and content when employers have proposed or implemented changes in work practices and work organisation which are deemed to have deleterious implications for journalists' job security, skills level and work intensity. For example, the NUJ Daily Record/Sunday Mail chapel's response to job losses in the picture retouching department was: 'This dispute is primarily about saving peoples' jobs, but it is also about maintaining the quality of the product' (Press Gazette 9 April 2004). Earlier, journalists at the Scotsman in 2002 called for the editorial director, Andrew Neil, to resign over the direction of papers, the damaged reputation of the paper and the eroding of the quality of the newspaper after passing a vote of 'no-confidence' in him. However, this rebellion was part of a wider process of a building up discontent at that time. Scotsman Publications journalists were 'awarded' a pay freeze, three departments across three papers (Scotsman, Evening News and Scotland on Sunday) were to be merged with consequent job losses, and working hours were becoming longer as a result of the non-replacement of staff. Indeed, working hours were expected to become longer after the merger of departments as a result of teething problems and the consequent reduction in staffing. The journalists concluded that in addition to the deleterious change in their conditions of work, the merging of departments and sacking of staff 'would be damaging to the papers' and would 'damage the titles' (Press Gazette 19 July 2002) and Neil's direction had raised 'concerns about the quality of content' (Independent 18 July 2002). In another example, and following after a reduction in the 
editorial 'headcount' at the Express Newspapers from 540 to 400 in 2001, the NUJ chapel balloted on strike action against further redundancies in 2004, with a member stating:

We've had a whole series of cuts over the years and the general consensus is that this is going too far. We have already probably the most cost-effective national newspapers and people feel that they are working very hard and under pressure already. It's only going to make matters worse for us as journalists and worse for the newspapers as a whole [emphasis added]'. (Press Gazette 23 April 2004)

Nearly twenty other instances of job cuts leading to a response from the NUJ that redundancies also detrimentally affect the quality of the newspapers have also been identified (see, for example, NUJ general secretary in Tribune 1 February 2008, NUJ Press Releases 25 November 2004, 7 January 2005, 17 August 2005, 19 October 2005, 1, 5, 6, 9 December 2005, 21, 28 January 2008, 19, 27 June 2008, Press Gazette 3 December 2004, 19 November 2004, 14 January 2005, 21 March 2005, 9 November 2007, 25 January 2008). Indeed, in the period of the NUJ's Journalism Matters campaign, which campaigned in the NUJ's own words to 'defend quality journalism' and ran from 2006 onwards), such statements became almost routine.

Other occasions of collective concern over editorial content expressed through the NUJ (workplace-based fathers and mothers of chapels (FoCs, MoCs) and NUJ employed officials speaking on behalf of chapels or the national union) speaking to the press have revolved around the use of business process reengineering and merging of operations within and across newspapers and their departments, and attendant retraining and alleged deskilling of journalists (UK Press Gazette 30 August 1993, 30 August 1995, 19 February 1996, 24 May 1996, Press Gazette 13 June 1997, Observer 10 March 2002). A similar array of instances can be found concerning the deleterious implications of low pay for the morale and motivation of existing journalists as well as the for the ability to recruit and retain young, good quality journalists during NUJ campaigns for higher pay. 
The discourse that NUJ has chosen to respond by is primarily one a trade union, where its concerns are with members' terms and conditions of employment. To support these, a secondary discourse concerned with the quality of journalism has then been employed in support, particularly as an overture to gaining the support of members of the public as consumers of newspapers (rather than fellow workers). Nonetheless, of all the instances when such responses might have been occasioned, these are, nonetheless, a minority. One example of how a union discourse easily dominates over an editorial discourse can be found at the Yorkshire Post in Leeds in 2004, when a dispute emerged between the NUJ chapel and the editor over the ending of the post of women's editor. At a chapel meeting attended by around 100 members, journalists passed a motion of 'no-confidence' in the editor and threatened to ballot on industrial action. The dispute concerned the resultant job loss being contrary to assurances of job security given by the new editor in a process of 'modernising' and 'developing' the paper (a process which the chapel did not disagree with the need for) and the way in which the proposed changes were being made, that is, without sufficient consultation and involvement. The result of the chapel's actions was that the member concerned was given another post of equal status to that of women's editor. But at no point did the chapel express any concerns about the issue of the implications of the ending of the post of women's editor for the coverage of women's issues.

The pattern of collective and union behaviour that emerges from these identified instances is one where under certain conditions of assaults upon journalists' terms and conditions of employment which generate considerable and widespread discontent, these assaults are also then perceived to have deleterious implications for journalists' conditions of work which in turn have deleterious implications for the standard and quality of journalism and editorial content. On these occasions the basis exists for the two concerns to enmesh. The highly 
specified means of expressing this highly contingent social process is required in order to distinguish and emphasise the nature and direction of causation where grievance identification, interest formation and attribution of the agency of resolution (i.e. management) can arise (see Kelly 1998). This formulation establishes the contingent nature of what can be termed a process of cognitive liberation, and serves to emphasise the need for contextualisation of processes to aid the understanding of outcome. This cognitive liberation process, where it occurs, provided the basis for the Birmingham Post and Mail FoC to argue, in proposing a motion at the NUJ annual delegates conference of 2004 condemning the costing-cutting, profit-seeking actions of newspaper employers, that:

In newsrooms the job losses mean falling standards and less time to go the extra yard for a better interview. They mean pulling in a crap press release when there's a real story out there that our readers would be interested in. ... We must defend our papers from the corporate vandals that would grind them into the ground. (Press Gazette 2 April 2004, Journalist May 2004)

However, the cognitive recognition process - as it has so far existed - has not created or provided a means by which to effectively gain redress of grievance in as much that 'union action' in the abstract is identified as the mechanism by which to force management to resolve the issue in a desired manner. Here 'union action' is a vague and unelaborated proposition that neither specifies the form of action, nor the forces to constitute taking the action. Thus, there exists a disarticulation between the consciousness of concerns and the means of agency (of action and resolution) where conceptually the two are linked only when a heightened state of consciousness amongst sufficient numbers of journalists becomes the prerequisite for the creation of an agency which then can be mobilised (or mobilise itself) to seek effective redress by, for example, industrial action. This disarticulation exists in two senses. 
One is that the NUJ annual conference, as the major gathering of the NUJ and decider of policy and strategy, is not wholly representative of the membership in terms of not merely ideological positions but also in terms of attachment and motivation with regard to union and profession. NUJ annual conference comprises primarily activists who are of a higher trade union consciousness than members although this is not to imply that there cannot be political agreement on this issue between members and activists. The salience of this is that when activists speak or when motions are passed, they do not speak for the entire membership (sic) and they do not necessarily speak for a majority of the membership in terms of high levels of commitment to enact the spirit or instructions of the contribution or motion. In other words, they are a vanguard which is necessarily in advance of the broader membership which they seek to represent.

The other sense is that, within the activist milieu, there is heterogeneity of thought over what can or could be achieved in regard of NUJ members taking effective collective action to regulate or influence editorial content. Activists generally believe that the union has a role in promoting journalists' collective actions to do so, but they differ sharply on how this can be done and if this can be done in the current period. The more left-wing, shading into the ultra-left, believe almost as an article of faith, through pointing to the existence of one or two cases, that journalists can do this if they have the right 'leadership' and if the 'rank-andfile' are sufficiently angry, organised and confident to do so. The less left-wing activists believe that such a goal is legitimate but that attaining this goal is beyond the consciousness and capacity of ordinary members at present. Neither viewpoint makes much attempt to go beyond these bald positions by examining the issues in terms of their social dynamics and setting because the debate and discussion are conducted at the level of polemic, propaganda and, occasionally, agitation. 


\section{Editorial quality concerns as adjuncts to union propaganda}

In the last two decades, the NUJ and many journalists have continually put the case that worthy and decent newspapers require that newspaper owners are concerned with producing newspapers in themselves rather than just as an activity to make profits and that for journalists to be well motivated and have good morale require well remunerated and treated staff (see, for example, Bourne $(1995,1996)$, Holleran (1998), Dear (Press Gazette 16 November 2001), Scotland on Sunday 12 January 2003). An example concerns the strike by journalists in Coventry for higher pay:

A paper that can't value its journalists can't value its readers. Senior journalists on this paper are paid less than the average in Coventry, less than dustbin men get paid. (Coventry Telegraph MoC, Press Gazette 17 June 2005)

Although this general argument has been made in a way that suggests that good pay and conditions are necessary, but without being sufficient, conditions of good newspapers, this activity is one of making propaganda against newspaper employers. The nature of this propaganda is one of general interest representation of journalists' and NUJ members' interests within public life but which does not involve their participation and is carried out from a position of weakness vis-à-vis the newspaper employers. Indeed, it would not be wholly inaccurate to say that making propaganda was one of the few things the NUJ could attempt to do in the period of the 1990s and early 2000s.

\section{Union members' political consciousness}


The preceding discussion has focussed primarily on the 'politics of production' and the labour process. However, the determining influences on journalists' behaviour cannot merely be explained by virtue of an examination of this terrain. To this examination, consideration of the influence of the NUJ as a national trade union must also be introduced. In the last twenty years, the NUJ in labour union political terms has been on the left. Since the election of John Foster (1992-2001) and then Jeremy Dear (2001-) as general secretaries, this position has moved further to the left of the political spectrum. The NUJ's national executive has also followed this trend. As with any recent internal elections within labour unions in Britain, turnouts remain low, with $30 \%$ being a relatively high turnout. In addition, there has always existed a specific, even idiosyncratic, nature to the NUJ's left-wing policy positions and values. These centre on issues of employment and industrial relations law like union recognition, on press freedom like protection of sources and against concentration of ownership and on international issues like supporting the creation of an independent state of Palestine. Most of these are directly related to the experiences of the NUJ in a way that is not true for other unions other than the broadcasting union, BECTU, because of the nature of NUJ members' work. Although affiliated to the TUC, the NUJ does not have a political fund and in 2004 rejected having one. In other words, these views and positions do not represent a worldview as such, much less a coherent, full-blown or radical one.

Relating this political consciousness to the issue of journalists' collective concern over editorial content, it would be erroneous to suggest that there would exist a necessary or developed connection between journalists as trade unionists and editorial concerns or between journalists as left-wing trade unionists and editorial concerns. Indeed, many journalists are not on the left, some are Conservative voters, union membership does not presuppose a single set of political beliefs, and many would oppose the notion that journalists should seek to collectively influence editorial content through their union (see 
Harcup 2007). The pertinence here is that to that extent that the NUJ as a union has any determining influences on journalists' behaviour in the workplace on editorial issues, this is likely to be very partial and selective across space, time and persons. The arguments and comments of radical NUJ members like Benn, Foot and Pilger on journalists collectively influencing editorial content remain those of well-respected and high-profile but lone individuals which at best find a resonance in debates disconnected from struggles over workplace issues.

\section{Discussion and conclusion}

Harcup (2002a, 2002b) argued for a positive link between NUJ strength and assertiveness, on the one hand, and the possibility of journalists acting collectively over ethical concerns, on the other, citing such instances in the provincial press and suggested that there may be signs of a re-awakening of interest about these issues amongst journalists in tandem with the reflowering of the NUJ's relative industrial prowess. This argument can be legitimately widened out to concern editorial content in general of newspapers. In doing so, this article has presented an analysis which seeks to use the foundation of Harcup's work to elucidate a broader analysis of journalists' propensity to take collective action over editorial concerns which revolves around the intersection of journalists' ideological and material interests. It has suggested while that a conceptualisation which takes its starting point of the NUJ as a collective union organisation of journalists is essential, in isolation, it remains somewhat narrow, and ultimately, lacks greater purchase. This is because there is a pressing need to contextualise the dynamic social agency of the NUJ in both specific and general terms within the social relations of production, distribution and exchange (and specifically the employment relationship). 
In doing so, two key points emerge. First, the circumstances in which journalists collectively show a propensity to manifest concern over editorial content, and even take collective action about it, must be located in an analysis of both the collective strength of the NUJ in the workplace and its ability to contest and influence journalists' working conditions in that arena. This is fundamentally about the creation of the resource of an independent power base (cf. Foot in Harcup (2002b:13) on 'discipline'). Second, journalists' strongly-held collective expressions over editorial content are more likely to emerge in situations where grievances arise over working conditions and the employment relationship as an adjunct and where journalists have recently been engaged in a collective action over wages and conditions or have maintained strong union organisation. While both suggest that the emergence or maintenance of robust collectivism and collective confidence are crucial, the former situations occasion relatively weaker expression and the latter stronger expression accompanied often by collective action. Nonetheless, both are predicated on the NUJ being a union that is also concerned with the function of the media from a critical perspective.

But these highly contingent occasions remain extremely limited, forcing our attention to consider the reasons for the paucity of such action. In historical terms, strike activity amongst journalists in newspapers in Britain has never been common. Relative to the industrial prowess of the print unions prior to their defeats at Warrington (1983) and Wapping (1986), the NUJ had not developed cohesive and assertive workplace unionism. Moreover, chapels operated in an autonomous way within a de facto federally structured NUJ. Following the Times and provincial newspaper strikes of 1978-1979, the process of developing workplace unionism may have been set in train but any prospect of it continuing, widening and deepening was stymied by the defeat of the print unions and then the employers' derecognition offensive. In tandem and thereafter, the NUJ was affected by the general disorganisation and demoralisation of labour unionism under Thatcherism and 'new' 
Labour. Aggregate strike activity remained low in the late 1990s and early 2000s. Such conditions of demobilisation have not been conducive to the raising collective concerns over editorial content, much less taking action over them.

This demobilisation effect is configured in a certain way that within member's consciousness a significant disarticulation exists between individual journalists having concerns about editorial content and their labour unionism having the capacity to resolve these. Consequently, individual journalists seldom attempt to raise the concerns in a collective environment, i.e., through their chapel. Those concerns that are raised focus on the more conventional economistic or 'bread and butter' issues of pay and conditions. In this situation, journalists on a day-by-day basis have come to reluctantly and unconsciously accept the hegemonic narrowed vision of their employers of what journalism is and this becomes internalised within them as they strive to meet copy deadlines and work with existing resources. Put another way round, such is the limited and weak nature of the contemporary process by which political and labour union consciousness develops that it would be naïve to expect journalists to take collective action over editorial content until and unless they also undertake sustained industrial struggles over pay and conditions. This causation arises because journalists, on the one hand, require the development of their intellectual and ideological resources to conceive that editorial content not only should be different but (actually) could be different, and can and should be subject to an element of collective control by journalists. On the other hand, this causation also arises because journalists require the attitudinal and behavioural resources to form a strong and independent power base from which act on these perspectives. In this way, we can begin to start conceptualising the paucity of journalists' collective challenge to the hegemony of the employers' discourse of what journalism is and what it should be. 
The salience and force of the analysis in this article would seem to be confirmed by the response of the NUJ and its membership to the effects of the credit-crunch and economic recession from late 2007 onwards, which has precipitated widespread job losses and redundancies amongst newspapers. While its Journalism Matters campaign has been maintained, it has been superseded by its Stand up for Journalism campaign of late 2007 onwards but which covers the same ground. Both campaigns are essentially national union political campaigns, articulated and constituted in the media by NUJ by its general secretary, with sprinklings of infrequent local actions. They are both campaigns for members rather than by members, and they inadvertently highlight the increased paucity - now nearing absence - of collective workplace based actions, especially industrial action, over redundancies and the consequent deleterious impact on editorial quality. Although the impact of the recession with regard to job losses provided for a situation by which NUJ members could have potentially mobilised themselves and a wider citizenship (of readers) in a rounded campaign of industrial action and public protest, this has not arisen because very few instances of industrial action (save those in Glasgow and Sheffield) have taken place upon which such campaigns could be based. Overwhelmed by the continual spate of job losses and with their labour market position consequently weakened, the journalists have protested in word - through press releases and public statements of their representatives but not in deed. However, much of the message of the protesting has concerned not the consequence of jobs losses for editorial quality but the juxtaposition of job losses to increasing company profits. These changed characteristics again underline the importance of understanding the dialectical interplay of agency and environment in the workplace and to do so across space and time.

\section{Notes}

'The attention of unions to issues of customer and consumer care for the products and services their members provide has not been a particularly developed one (Heery 1993). 
ii The Institute of Journalists (IOJ) and the British Association of Journalists (BAJ) as organisations by the extent of their membership are almost irrelevant.

iii By contrast, the IOJ and BAJ emphasise far more their profession-al role and far less their union or industrial role.

iv Although very infrequent, cases of state editorial interference in public broadcasting (radio, television) in Britain have occasioned more robust collective responses from the NUJ and these have become higher profile disputes in the public domain (see Gopsill and Neale 2007). The reasons for this are because such state action within national media organisations is regarded as much more threatening to editorial independence and because in these circumstances of outside, third-party intervention, management can be supportive of NUJ which legitimates it and makes it more attractive to journalists to be involved in.

\section{References}

Beharell, P. and Philo, G. (1977) (eds.) Trade Unions and the Media, Macmillan, London. Bourne, C. (1995) 'Papers before profit' Journalist, December, pp18-19.

Bourne, C. (1996) Letter, UK Press Gazette, 30 August, p10.

Bromley, M. (1997) 'The End of Journalism? Changes in workplace practices in the press and broadcasting in the 1990s' in Malley, T. and Bromley, M. (eds.) A Journalism Reader, Routledge, London, pp330-350.

Browne, A. (2002) 'You can't trust those dirty, lying hacks' New Statesman 10 June, pp20-21. Davies, N. (2008) Flat Earth News: An Award-winning Reporter Exposes Falsehood, Distortion and Propaganda in the Global Media, Chatto and Windus, London.

Foot, P. (1991) 'Strenuous liberty ... a nervous revival?' British Journalism Review, 2/4:5-8.

Franklin, B. and Murphy, D. (1991) What News? The Market, Politics and the Local Press, Routledge, London.

Franklin, B. and Murphy, D. (1997) 'The Local Rag in Tatters? The decline of Britain's local newspapers' in Malley, T. and Bromley, M. (eds.) A Journalism Reader, Routledge, London, pp214-228.

Franklin, B. and Murphy, D. (eds.) (1998) Local Newspapers, local media and local journalism, Routledge, London.

Frost, C. (2007) Journalism, Ethics and Regulation, second edition, Pearson Longman, Harlow.

Gall, G. (1993) 'Journalism for changing times: the impact of new technology and industrial relations on the editorial content of the provincial press' Political Studies Association Conference, Leicester.

Gall, G. (1997) 'Looking in the Mirror: a case study of industrial relations in a national newspaper' in Malley, T. and Bromley, M. (eds.) A Journalism Reader, Routledge, London, pp233-246.

Gall, G. (2002) 'The return of the National Union of Journalists to the provincial newspaper industry in Britain?' Media, Culture and Society, 24/5:673-692.

Gall, G. (2005a) 'Back from the brink or still on the margins? The NUJ in the provincial newspaper industry in Britain' Journalism, 6/4:421-441.

Gall, G. (2005b) 'The NUJ and the provincial newspaper industry- from derecognition to recognition to fraught bargaining' in Gall, G. (ed.) Union Recognition: Organising and Bargaining Outcomes, Routledge, London, pp115-133.

Gall, G. and Murphy, D. (1996) 'Journalism in changing times; the changing relationship between trade unionism and professionalism in the British provincial newspaper industry' in Fincham, R. (ed.) New Relationships in the Organised Professions, Avebury, Aldershot, pp225246.

Gopsill, T. and Neale, G. (2007) Journalists: one hundred years of the NUJ, Profile, London. 
Greenslade, R. (2003) Press Gang: how newspapers make profit from propaganda, Macmillan, London.

Harcup, T. (2002a) 'Journalists and Ethics: the quest for a collective voice' Journalism Studies, 3/1:101-114.

Harcup, T. (2002b) 'Conduct unbecoming? Press Gazette 1 March, p13.

Harcup, T. (2004) Journalism: Principles and Practice, Sage, London.

Harcup, T. (2007) The Ethical Journalist, Sage, London.

Heery, E. (1993) 'Industrial relations and the customer' Industrial Relations Journal, 24/4:284-295.

Holleran, P. (1998) 'Privacy, profit and press freedom' Scottish Socialist Voice 13 November, p2.

Hollingsworth, M. (1986) The Press and Political Dissent: a question of censorship, Pluto, London.

Keeble, R. (2001) Ethics for Journalists, Routledge, London.

Kelly, J. (1998) Rethinking Industrial Relations: mobilization, collectivism and long waves, Routledge, London.

Sanders, K. (2003) Ethics and Journalism, Sage, London.

Sparks, C. (1999) 'The press' in Stokes, J. and Reading, A. (eds.) The Media in Britain: Current debates and developments, Macmillian, Basingstoke, pp41-60.

Tunstall, J. (1971) Journalists at Work- specialist correspondents: their news organizations, news sources and competitor-colleagues, Constable, London.

\section{Appendix}

The NUJ's Code of Conduct, adopted in 1936, requires that all members must strive to adhere to it. It comprises:

1. A journalist has a duty to maintain the highest professional and ethical standards.

2. A journalist shall at all times defend the principle of the freedom of the press and other media in relation to the collection of information and the expression of comment and criticism. He/she shall strive to eliminate distortion, news suppression and censorship.

3. A journalist shall strive to ensure that the information he/she disseminates is fair and accurate, avoid the expression of comment and conjecture as established fact and falsification by distortion, selection or misrepresentation.

4. A journalist shall rectify promptly any harmful inaccuracies, ensure that correction and apologies receive due prominence and afford the right of reply to persons criticised when the issue is of sufficient importance.

5. A journalist shall obtain information, photographs and illustrations only by straightforward means. The use of other means can be justified only by overriding considerations of the public interest. The journalist is entitled to exercise a personal conscientious objection to the use of such means.

6. A journalist shall do nothing which entails intrusion into anybody's private life, grief or distress, subject to justification by overriding considerations of the public interest.

7. A journalist shall protect confidential sources of information.

8. A journalist shall not accept bribes nor shall he/she allow other inducements to influence the performance of his/her professional duties.

9. A journalist shall not lend himself/herself to the distortion or suppression of the truth because of advertising or other considerations.

10. A journalist shall mention a person's age, sex, race, colour, creed, illegitimacy, disability, marital status, or sexual orientation only if this information is strictly relevant. A journalist shall neither originate nor process material which encourages discrimination, ridicule, prejudice or hatred on any of the above-mentioned grounds. 
11. No journalist shall knowingly cause or allow the publication or broadcast of a photograph that has been manipulated unless that photograph is clearly labelled as such. Manipulation does not include normal dodging, burning, colour balancing, spotting, contrast adjustment, cropping and obvious masking for legal or safety reasons.

12. A journalist shall not take private advantage of information gained in the course of his/her duties before the information is public knowledge.

13. A journalist shall not by way of statement, voice or appearance endorse by advertisement any commercial product or service save for the promotion of his/her own work or of the medium by which he/she is employed. 